\title{
In vitro Evaluation of the Thermal Alterations on the Root Surface During Preparation with Different Ni-Ti Rotary Instruments
}

\author{
Alexandre CAPELLI \\ Danilo M. Zanello GUERISOLI \\ Eduardo Luiz BARBIN \\ Júlio César Emboava SPANÓ \\ Jesus Djalma PÉCORA \\ Department of Restorative Dentistry, Faculty of Dentistry of Ribeirão Preto, University of São Paulo, \\ Ribeirão Preto, SP, Brazil
}

\begin{abstract}
The present study evaluated, in vitro, the temperature alterations on the external root surface during instrumentation with four different rotary systems. A total of 20 extracted human maxillary lateral incisors were instrumented using either the ProFile, MicroMega, Quantec or $\mathrm{K}^{3}$ systems and the thermal alterations on the root surface were recorded by means of three thermocouples attached to the coronal, middle and apical portions of the root. Mean temperature increases no higher than $0.4^{\circ} \mathrm{C} \pm 1.0^{\circ} \mathrm{C}$ (ProFile system) were recorded, which indicates that these instruments are safe for the surrounding periodontal tissues.
\end{abstract}

Key Words: thermal alterations, rotary instruments, nickel-titanium.

\section{INTRODUCTION}

Techniques that induce heat inside the root canal, such as obturation with thermoplasticized guttapercha, post space preparation and intracanal laser irradiation, led to quantification of the temperature changes on the root surface and possible periodontal tissue damage (1-4).

Saunders and Saunders (1) measured, in vitro, the heat generated on the external root surface of human premolar teeth during post space preparation. The rise in temperature was recorded at a point $6 \mathrm{~mm}$ from the apex of the tooth using a thermocouple attached to a chart recorder. The temperature increase was greatest when the removal of gutta-percha was combined with post channel preparation, with temperature increases of up to $31^{\circ} \mathrm{C}$ recorded. The results from this study suggest that the use of motor-driven drills to prepare post channels in teeth may generate temperature increases that may cause periradicular tissue damage, and caution should be exercised during their use.

Saunders $(5,6)$ evaluated, in vivo, the heat generation during thermomechanical compaction of guttapercha. There was no statistically significant difference between temperature elevations recorded in vitro and those measured in vivo, which validates in vitro experiments using the same methodology. According to this author, temperature elevations of $10^{\circ} \mathrm{C}$ above body temperature, of duration greater than $1 \mathrm{~min}$, may be sufficient to cause bone tissue injury.

Tjan and Abbate (2) compared the changes in temperature at the root surface of extracted human central incisors during post space preparation using different instruments (Peeso, Kurer, Gates-Glidden and Para-Post drills and diamond burs). A mean temperature increase ranging from $2.3-15.6^{\circ} \mathrm{C}$ from baseline of approximately $28^{\circ} \mathrm{C}$ was recorded. The highest temperatures were recorded with Peeso reamers, whereas

Correspondence: Prof. Dr. Jesus Djalma Pécora, Faculdade de Odontologia de Ribeirão Preto, Universidade de São Paulo, Av. do Café s/n, Cidade Universitária, 14040-904 Ribeirão Preto, SP, Brasil. Tel: +55-16-602-3982. e-mail: pecora@forp.usp.br 
the lowest were recorded with Gates-Glidden and ParaPost systems.

The introduction of nickel-titanium rotary instruments incorporated a series of conceptual changes in root canal preparation. These instruments are activated by a low-speed electric or pneumatic motor, with speeds around $300 \mathrm{rpm}$, and can reach the whole extent of the root canal. Good results have been shown reducing intervention time and causing little or no canal transportation (7-11). Part of the friction generated inside the root canal during instrumentation produces heat, and the higher the rotation speed, the higher will be the temperature increase (12).

One of the main objectives in dental research is to investigate the therapeutic methods and the use of instruments and techniques that may generate or transmit heat to the dentine, since it may be harmful to the tooth and adjacent tissues. Thus, the present study aimed to evaluate, in vitro, the temperature alterations on the external root surface during instrumentation with four different rotary systems.

\section{MATERIAL AND METHODS}

A total of 20 extracted human maxillary lateral incisors obtained from laboratory stock and kept at $9^{\circ} \mathrm{C}$ in $0.1 \%$ thymol solution were used. Only teeth with totally formed roots were selected. The samples were washed in running water for $24 \mathrm{~h}$ in order to eliminate all thymol residues.

The canal length was visually established by

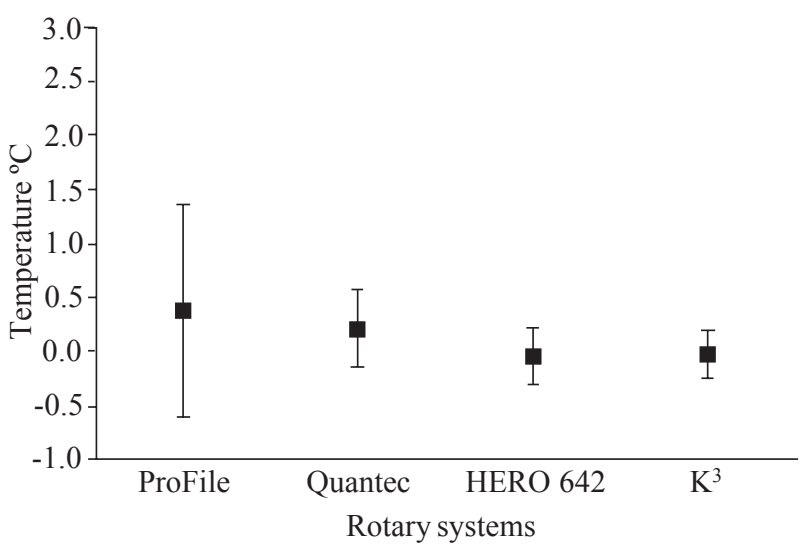

Figure 1. Temperatures obtained during the use of rotary systems for root canal preparation. placing a size $10 \mathrm{~K}$-type file (Dentsply-Maillefer, Ballaigues, Switzerland) into each root canal until the tip was visible at the apical foramen. Working length was established $1 \mathrm{~mm}$ short of the apex.

The samples were randomly divided into 4 groups of 5 teeth each, according to the nickel-titanium rotary system used for root canal preparation, as follows: group 1: instrumentation with ProFile system (DentsplyMaillefer, Ballaigues, Switzerland) initiated with the orifice shaper (50/.07), followed by 40/.06, 30/.06, 25/ .06 and 20/.06 instruments; group 2: instrumentation with HERO 642 system (MicroMega, Besançon, France) in the following sequence: 30/.06, 30/.04, 25/.06, 25/ $.04,20 / .06$ and 20/.04; group 3: instrumentation with the Quantec system (Sybron-Kerr, Mexico), initially with $25 / .12$ and then $25 / .08,25 / .06,25 / .04,20 / .06$ and 20/.04; group 4: instrumentation with $\mathrm{K}^{3}$ files (SybronKerr, Mexico), in the following sequence 30/.06, 30/ $.04,25 / .06,25 / .04,20 / .06$ and, 20/.04.

Each instrument was used inside the root canal for $10 \mathrm{~s}$ for all groups.

The teeth were placed in an acrylic apparatus fixed by their coronal part, in order to facilitate instrumentation and allow the placing of the thermocouple. On the external surface of the root, three copper-constantan thermocouples (type T, Consitec, São Paulo, SP, Brazil) were positioned and connected to multimeters (DMM916, Tektronix Inc., Beaverton, OR, USA) in order to register the thermal alterations at the apical, middle and coronal thirds of the roots. Temperature variations before and after instrumentation were registered.

Irrigation of the root canals was performed with $1 \%$ sodium hypochlorite, using a 30 gauge needle.

ANOVA was used for statistical analysis $(\mathrm{p}<0.05)$.

\section{RESULTS}

Temperature variation was calculated by the difference between initial and final values registered by the multimeter, at apical, middle and cervical thirds.

There was a non-significant difference $(\mathrm{p}>0.05$, ANOVA) between groups and root thirds regarding thermal variations. The ProFile $\left(0.4^{\circ} \mathrm{C} \pm 1.0^{\circ} \mathrm{C}\right)$, Quantec $\left(0.2^{\circ} \mathrm{C} \pm 0.3^{\circ} \mathrm{C}\right)$, MicroMega $\left(0.0^{\circ} \mathrm{C} \pm 0.3^{\circ} \mathrm{C}\right)$ and $\mathrm{K}^{3}$ $\left(0.0^{\circ} \mathrm{C} \pm 0.2^{\circ} \mathrm{C}\right)$ systems showed similar results. Figure 1 illustrates graphically the results obtained in this experiment. 


\section{DISCUSSION}

Temperature alterations transmitted to the root surface may be harmful to the surrounding tissues, because the heat generated inside the canal dissipates through dentine, reaching the cementum, periodontal ligament and alveolar bone (13). Some authors report that a temperature increase higher than $10^{\circ} \mathrm{C}$ from the basal level causes irreversible damage to these structures (14).

The present study demonstrated that none of the systems tested (ProFile, Hero, Quantec and $\mathrm{K}^{3}$ ) produced temperature increases higher than the established critical value of $10^{\circ} \mathrm{C}$. This is probably due to the fact that dentine is a poor heat conductor (15). However, according to Eriksson and Albrektsson (14), some additional factors can contribute to higher or lower temperature dissipation, such as anatomical diameter of the root canal and the amount of remaining dentine. Moreover, the presence of tissular fluids in the dentinal tubules and the vascularization at the periapical region can decrease the thermal effects (15).

Some of the temperatures registered for the thermal variations were lower than zero, thus cooling and not heating the external surface of the root.

Nickel-titanium rotary instruments work with a revolving speed between 150 and $300 \mathrm{rpm}$, far less than mechanical gutta-percha termoplastification (16) and post space preparation techniques (17), which use speeds of $8,000 \mathrm{rpm}$. Thus, the revolution speed of the instruments inside the root canal also interferes in the heat production and its transmission to the external surface since, in this case, speed is directly proportional to heat (12).

In the present study, the highest mean thermal variation was $0.4^{\circ} \mathrm{C} \pm 1.0^{\circ} \mathrm{C}$ (ProFile system), a value that is below the maximum tolerated by the surrounding supporting tissues, which is $10^{\circ} \mathrm{C}(15)$. The values for thermal alterations observed in the present experiment are below those reported for other procedures, such as the use of drills during post space preparation, thermomechanical obturation with McSpadden gutta-percha compactors and gutta-percha removal techniques $(1,2,5,6,12,18)$.

Thus we conclude that the heat generated by the ProFile, MicroMega, Quantec and $\mathrm{K}^{3}$ systems was below the maximum values tolerated by the surrounding periodontal tissues and, thus, may be considered bio- logically safe and free of harmful thermal effects.

\section{RESUMO}

O presente estudo avaliou, in vitro, as alterações térmicas na superfície externa radicular de dentes submetidos à instrumentação rotatória com quatro sistemas diferentes. Um total de 20 incisivos laterais superiores humanos foram divididos em 4 grupos e instrumentados com os sistemas ProFile, MicroMega, Quantec ou $\mathrm{K}^{3}$, sendo as variações térmicas da superfície radicular registradas por meio de 3 pares termoelétricos acoplados aos terços cervical, médio e apical das raízes dos dentes. Variações médias de temperatura não superiores a $0.4^{\circ} \mathrm{C} \pm 1.0^{\circ} \mathrm{C}$ foram registradas (sistema ProFile), o que indica que estes instrumentos são seguros do ponto de vista biológico aos tecidos periodontais circunjacentes.

\section{REFERENCES}

1. Saunders EM, Saunders WP. The heat generated on the external root surface during post space preparation. Int Endod J 1989;22:169-173.

2. Tjan AHL, Abbate MF. Temperature rise at root surface during post space preparation. J Prost Dent 1993;69:41-45.

3. Weller RN, Koch KA. In vitro temperatures produced by a new heated injectable gutta-percha system. Int Endod J 1994;27:299303.

4. Pécora JD, Marchesan MA, Guerisoli DMZ, Barbin EL, Brugnera-Júnior A. In vitro evaluation of external root temperature changes during Er:YAG laser application with five different fiberoptic tip withdrawal techniques. Laser Surg Med 2002;14:18.

5. Saunders EM. In vivo findings associated with heat generation during thermomechanical compaction of gutta-percha. Part I: Temperature levels at the external surface of the root. Int Endod $\mathbf{J}$ 1990;23:263-267.

6. Saunders EM. In vivo findings associated with heat generation during thermomechanical compaction of gutta-percha. Part II: Histological response to temperature elevation on the external surface root. Int Endod J 1990;23:268-274.

7. Serene TP, Adams JD, Saxena A. Nickel-Titanium Instruments: Applications in Endodontics. St. Louis, MO: Ishiyaku Euroamerica, 1995.

8. Thompson SA, Dummer PM. Shaping ability of ProFile .04 taper series 29 rotary nickel-titanium instruments in simulated root canals: Part 1. Int Endod J 1997;30:1-7.

9. Thompson SA, Dummer PM. Shaping ability of ProFile .04 taper series 29 rotary nickel-titanium instruments in simulated root canals: Part 2. Int Endod J 1997;30:8-15.

10. Buchanan LS. The standardized-taper root canal preparation. Part I: concepts for variably tapered shaping instruments. Int Endod J 2000;33:516-529.

11. Buchanan LS. The standardized-taper root canal preparation. Part II: file selection and safe handpiece-driven file use. Int Endod J 2001;34:63-71.

12. Hardie E. Further studies on heat generation during obturation techniques involving thermally softened gutta-percha. Int Endod J 1987;20:122-127.

13. Atrizadeh F, Kennedy J, Zander H. Ankylosis of the teeth following thermal injury. J Periodontol Research 1971;49:752-755.

14. Eriksson AR, Alberektsson T. Temperature threshold levels for 
heat-induced bone tissue injury: A vital microscopic study in the rabbit. J Prost Dent 1983;50:101-106.

15. Weller RN, Koch KA. In vitro radicular temperatures produced by injectable thermoplasticized gutta-percha. Int Endod $\mathrm{J}$ 1995;28:86-90.

16. Tagger M. Use of thermo-mechanical compactors as an adjunct to lateral condensation. Quintessence Inter 1984;15:27-30.
17. Hussey DL, Biagioni PA, McCullagh JJP, Lamey PJ. Thermographic assessment of heat generated on the root surface during post space preparation. Int Endod J 1997;30:187-190.

18. Fors U, Jonasson E, Berquist A, Berg JO. Measurements of the root surface temperature during thermo-mechanical root canal filling in vitro. Int Endod J 1985;18:199-202.

Accepted March 15, 2004 